\title{
Leucocyte endothelial cell adhesion in indomethacin induced intestinal inflammation is correlated with faecal $\mathrm{pH}$
}

\author{
H Arndt, K-D Palitzsch, J Schölmerich
}

\begin{abstract}
Background-Recent studies indicate that faecal $\mathrm{pH}$ is acidified in patients with inflammatory bowel disease compared with healthy controls. In healthy volunteers, stool pH, faecal flora, and bile acid concentration could be affected by means of elemental diets.

Aims-To assess the role of variations of faecal pH on leucocyte endothelial cell adhesion in indomethacin induced long lasting ileitis in rats.

Methods-Indomethacin $(7.5 \mathrm{mg} / \mathrm{kg}$ subcutaneously) was injected twice, 24 hours apart. Rats were either fed with the identical diet before and $\mathbf{1 0}$ days after the induction of inflammation until the experiment, or the diet was changed at the time of induction. Ten postcapillary mesenteric venules ( $30 \mu \mathrm{m}$ diameter) per animal were observed using intravital microscopy. Macroscopic visible intestinal ulceration was scored and faecal $\mathrm{pH}$ of different sections of the small bowel was determined.
\end{abstract}

Results-Small intestinal faecal pH was 8.5 in controls and 8.0 in indomethacin treated animals. Indomethacin significantly changed microcirculatory parameters: there was a 2.3-fold increase in leucocyte adherence, a 3.2-fold increase in leucocyte emigration, and a $20 \%$ reduction in shear rate. Application of various diets or diet combinations resulted in variations in faecal $\mathrm{pH}$ ranging from 7.8 to 8.8 which were inversely correlated with macroscopic ulcerations $(r=-0.67)$. Leucocyte adherence was attenuated with increased $\mathrm{pH}$ and augmented with decreased $\mathrm{pH}(r=-0.55)$. Venular wall shear rate was positively correlated with faecal pH $(r=0.48)$ while leucocyte emigration showed no correlation. Leucocyte rolling velocity was not significantly altered. Normalisation of faecal $\mathrm{pH}$ by different alkalising drugs induced a significant decrease in leucocyte adherence in standard fed, indomethacin treated rats.

Conclusions-Faecal pH is lowered in the indomethacin model of long lasting ileitis in rats, which is similar to human inflammatory bowel disease. Alkalisation of faecal pH due to different diets or alkalising drugs reduces indomethacin induced leucocyte endothelial cell adhesion and macroscopic intestinal damage. These results may provide a rationale for the therapeu- tic effect of enteral diets in Crohn's disease.

(Gut 1998;42:380-386)

Keywords: faecal $\mathrm{pH}$, indomethacin, inflammatory bowel disease, diet, intravital microscopy

Several luminal factors have been implicated in the pathogenesis of inflammatory bowel disease (IBD). Among these, bacteria and bacterial products, nutritional metabolites, and faecal bile acid pattern are under investigation. The important role of enteric bacteria in initiating and/or perpetuating intestinal inflammation in IBD and animal models of IBD is illustrated by the attenuation of inflammation in germ free rats ${ }^{1}$ and the beneficial effect of antimicrobial agents like metronidazole, on inflammatory activity in patients ${ }^{2}$ and experimental animals. ${ }^{34}$ The influence of nutrition has been shown by the effect of bowel rest using total parenteral nutrition ${ }^{5}$ or elemental diets. ${ }^{67}$ Furthermore, dietary habits seem to be different between patients with IBD and healthy subjects. ${ }^{8}$

Little is known about a possible effect of the intraluminal intestinal $\mathrm{pH}$ on inflammatory activity in IBD. In a clinical study the faeces of patients with IBD had a lower $\mathrm{pH}$ than faeces of healthy subjects. ${ }^{9}$ Faecal $\mathrm{pH}$ may be affected by faecal bile acid pattern, luminal bacteria, and nutritional metabolites, parameters which can also affect each other. ${ }^{10-14}$ Intraluminal $\mathrm{pH}$ may be shifted by the bacterial profile. ${ }^{10}$ Enss et $a l^{15}$ showed that colonic mucins are acidified after polyvalent bacterial colonisation of germ free rats. Certain species may be favoured by the application of different diets. ${ }^{16}$ Bacterial conversion from primary to secondary bile acids might be altered by variations in intestinal flora. ${ }^{9}$ Alternatively intestinal $\mathrm{pH}$ may be changed by administration of antagonists of bicarbonate secretion. ${ }^{17}$

The objective of this study was to assess the role of small bowel faecal $\mathrm{pH}$ on leucocyte endothelial cell interaction in postcapillary mesenteric venules in indomethacin induced long lasting ileitis in rats. Sublethal doses of indomethacin produce chronic inflammation of the distal jejunum and proximal ileum that persists for more than 11 weeks in genetically susceptible rats. ${ }^{18} 19$ The clinical, histological, and pathophysiological features of indomethacin induced lesions are similar to those in Crohn's disease, and are characterised by thickening of the small intestine and mesentery, adhesions, obstructions, linear mucosal ulcerations, acute
Dr Arndt.

Accepted for publication 7 August 1997 
Table 1 Composition of the various diets

\begin{tabular}{llllllllll}
\hline Diet & $\begin{array}{l}\text { Fibre } \\
(\mathrm{mg} / \mathrm{kg})\end{array}$ & $\begin{array}{l}\text { Protein } \\
(\mathrm{mg} / \mathrm{kg})\end{array}$ & $\begin{array}{l}\text { Carbohydrate } \\
(\mathrm{mg} / \mathrm{kg})\end{array}$ & $\begin{array}{l}\text { Fat } \\
(\mathrm{mg} / \mathrm{kg})\end{array}$ & $\begin{array}{l}\text { SFA } \\
(\mathrm{mg} / \mathrm{kg})\end{array}$ & $\begin{array}{l}\text { MUFA } \\
(\mathrm{mg} / \mathrm{kg})\end{array}$ & $\begin{array}{l}\text { PUFA } \\
(\mathrm{mg} / \mathrm{kg})\end{array}$ & $\begin{array}{l}\text { Cholesterol } \\
(\mathrm{mg} / \mathrm{kg})\end{array}$ & $\begin{array}{l}\text { Energy } \\
(\mathrm{MF} / \mathrm{kg})\end{array}$ \\
\hline ST & 4.0 & 17.3 & 58.3 & 5.1 & 0.4 & 1.1 & 3.6 & - & 14.63 \\
CH & 2.0 & 12.3 & 69.2 & 3.0 & 0.3 & 0.7 & 2.1 & - & 15.01 \\
FR & 4.0 & 17.2 & 44.4 & 16.1 & 1.4 & 3.6 & 11.4 & - & 15.88 \\
FP & 4.0 & 17.3 & 58.3 & 0.08 & - & - & - & - & 13.80 \\
CR & 4.0 & 15.3 & 52.7 & 15.8 & 12.0 & 2.2 & 1.0 & 1.0 & 16.30 \\
CP & 4.1 & 17.0 & 63.1 & 5.1 & 0.8 & 3.8 & 0.5 & - & 15.01 \\
SA & 4.0 & 17.3 & 58.3 & 5.1 & 0.4 & 0.9 & 3.8 & - & 14.63 \\
US & 4.0 & 17.3 & 58.3 & 5.1 & 4.4 & 0.3 & 0.4 & - & 14.63 \\
\hline
\end{tabular}

SFA, saturated fatty acids; MUFA, monounsaturated fatty acids; PUFA, polyunsaturated fatty acids; ST, standard diet; $\mathrm{CH}$, diet rich in carbohydrates, FR, diet rich in fatty acids; FP, diet poor in fatty acids; CR, diet rich in cholesterol; CP, diet poor in cholesterol; SA, diet poor in saturated fatty acids; US, diet poor in unsaturated fatty acids.

and chronic transmural granulomatous inflammation, crypt abscesses, and fibrosis. ${ }^{20} 21$

In our experiments intestinal $\mathrm{pH}$ was varied by feeding with different diets (standard laboratory rat chow or combinations of commercially available isoenergetic special diets). In some groups ion exchangers were used to increase faecal $\mathrm{pH}$. The effect of various diet combinations and ion exchangers on intestinal $\mathrm{pH}$ was determined 10 days after indomethacin administration by intravital microscopy in order to characterise the influence of $\mathrm{pH}$ modification on leucocyte endothelial cell interaction.

\section{Methods}

EXPERIMENTAL PROTOCOL

One hundred and fifty male Sprague-Dawley rats (160-240 g) were housed for two weeks in a room with a constant temperature of $25^{\circ} \mathrm{C}$ and a 12:12 hour light:dark cycle. They were given water and standard laboratory rat chow (ST) or different diets ad libitum (rich in carbohydrates, $\mathrm{CH}$; rich in fatty acids, FR; poor in fatty acids, FP; rich in cholesterol, CR; poor in cholesterol, CP; poor in saturated fatty acids, SA; poor in unsaturated fatty acids, US; Altromin, Germany; table 1) for 14 days before the induction of inflammation. Previous experiments had shown that the various diets are accepted by the rats to a similar extent. Thus there was no difference in daily food intake or in the time of refeeding after indomethacin administration due to avoidance of certain diets (data not shown). Animals received two subcutaneous injections of indomethacin (10 $\mathrm{mg} / \mathrm{ml}$ in $5 \% \mathrm{NaHCO}_{3}, 7.5 \mathrm{mg} / \mathrm{kg}$ each), 24 hours apart. After the first injection of indomethacin, animals were fed with standard rat chow or a special diet for a further 10 days.

Some animals fed with standard diet were gavaged once a day for 10 days until the experiment with either potassium hydrogen citrate $(120 \mathrm{mg} / \mathrm{kg})$, polysulphonic acid (150 $\mathrm{mg} / \mathrm{kg}$ ), or cholestyramine $(60 \mathrm{mg} / \mathrm{kg})$. The doses chosen were similar to those used in humans. These animals received either two injections of indomethacin or indomethacin vehicle.

Overall, 26 groups (five rats each) of different diet combinations (table 2) were tested within six months. The positive control group fed with standard rat chow continuously also received two injections of indomethacin, while the negative control group (with standard diet) received two subcutaneous injections of the indomethacin vehicle at similar time points. To ensure reproducibility of the data, three sets of positive controls ( $\mathrm{n}=5$ animals each) were tested over the six month period, and no significant differences in microcirculatory parameters between these groups were obtained. Animals were immediately refed after the injection and fasted $12-18$ hours prior to the experiments. Previous experiments had shown that different diet combinations without induction of inflammation by indomethacin did not alter leucocyte endothelial cell interaction (data not shown). To check whether the appearance of pathological bacteria could be responsible for the microcirculatory differences measured, the small intestinal contents of two animals from each group were tested, but no pathogens could be detected.

\section{ANIMAL PREPARATION}

After anaesthesia with pentobarbital $(40 \mathrm{mg} /$ 100 g body weight) tracheotomy was performed, and the left carotid artery was cannulated for continuous measurement and recording of systemic blood pressure and heart rate (Statham P23A Transducer, Oxnard, California; Grass Recorder, Grass Instruments, Quincy, Massachusetts).

\section{INTRAVITAL MICROSCOPY}

Rats were placed in a supine position on an adjustable Plexiglas microscope stage and the exteriorised segment of the mid-jejunum was draped over an optically clear viewing pedestal, allowing transillumination of a $2 \mathrm{~cm}^{2}$ section, as described previously. ${ }^{22}$ The exposed bowel wall was draped with saline soaked gauze, and the mesentery was continuously superfused with warm bicarbonate buffered salt solution (BBS, pH 7.4) bubbled with $5 \% \mathrm{O}_{2} / 95 \% \mathrm{~N}_{2}$. The temperature of the pedestal was maintained at $37^{\circ} \mathrm{C}$ by a constant temperature circulator (Fisher Scientific, model 80). Single unbranched mesenteric venules $25-35 \mu \mathrm{m}$ in diameter and approximately $150 \mu \mathrm{m}$ long were transilluminated with a $12 \mathrm{~V}, 100 \mathrm{~W}$ light source and observed through an intravital videomicroscope (Nikon Diaphot, Japan) with a $\times 40$ objective lens (Nikon UD 40/0.65, Japan) and a $\times 10$ eyepiece. A videocamera (Hitachi WK-C150, Japan) mounted on the microscope, projected the image onto a colour monitor (Sony PVM-2030, Japan). Venular diameter $\left(D_{v}\right)$ was measured using a video image shearing monitor (Microcirculation Research Institute, Texas A\&M University). Red 
blood cell centreline velocity was measured on line with an optical Doppler velocimeter (Microcirculation Research Institute, Texas A\&M University). Mean red blood cell velocity was calculated assuming $\mathrm{V}_{\text {mean }}=$ centreline velocity/1.6. ${ }^{24}$ Venular shear rate $(\gamma)$ was calculated based on the Newtonian definition ${ }^{25}$ : $\gamma=8\left(\mathrm{~V}_{\text {mean }} / \mathrm{D}_{\mathrm{v}}\right)$. When all parameters measured on line (arterial pressure, erythrocyte velocity, venular diameter) were in a steady state during superfusion with BBS, images from the mesenteric preparations were videotaped using a videocasette recorder (Panasonic NV8950, Japan) for five minutes. Approximately 10 venules per animal were monitored for playback analysis.

The numbers of adherent and emigrated leucocytes were determined during playback of videotaped images. A leucocyte was defined as adherent to venular endothelium if it was stationary for at least 30 seconds. Leucocyte adherence was expressed as the number per $100 \mu \mathrm{m}$ length of the venule. Leucocyte emigration was expressed as the number of white blood cells per microscopic field $(1.7 \times$ $10^{-2} \mathrm{~mm}^{2}$ ). Rolling leucocytes were defined as white blood cells moving at a slower velocity than erythrocytes in the same vessel. Leucocyte rolling velocity $\left(\mathrm{V}_{\mathrm{wbc}}\right)$ was determined from the time a leucocyte took to move along $100 \mu \mathrm{m}$ of the microvessel. A mean of 10 estimates of transit time was used to calculate $V_{\text {wbc }}$.

FAECAL pH MEASUREMENT

Following intravital microscopy the animals were sacrificed with an overdose of pentobarbital. The small intestine was excised and divided into sections $(0-20 \mathrm{~cm}$ from caecum towards proximal end, $20-30 \mathrm{~cm}$, and then further 10 $\mathrm{cm}$ sections until the ligament of Treitz, the overall small bowel length varying from 80 to
$100 \mathrm{~cm}$ ). After opening each section longitudinally the luminal contents were dissolved separately for each section in $\mathrm{NaCl}(0.9 \%, 1 / 10$ dilution) and faecal $\mathrm{pH}$ was determined. For control purposes, faecal $\mathrm{pH}$ was in some cases measured by a microelectrode which was placed directly into the luminal contents of the opened ileum $10 \mathrm{~cm}$ proximal to the caecum; there was, however, no difference in the $\mathrm{pH}$ measured in the dissolved faeces.

TISSUE ANALYSIS

Following intravital microscopy the animals were sacrificed with an overdose of pentobarbital and the intestines were excised and opened longitudinally. Gross findings were ranked using the following criteria: $0-$ no change in serosa or mucosa; 1-hyperaemic lesions and/or petechial bleeding; 2-single mucosal erosion or ulceration; 3-multiple erosions or ulcerations without any lesions in the serosa and mesentery, or single mucosal ulceration or ulcer with hyperaemic, adhesive, or haemorrhagic lesions in the serosa; 4-multiple erosions or ulcerations (on less than $10 \mathrm{~cm}$ of bowel length) with hyperaemic, adhesive, or haemorrhagic lesions in the serosa; 5-multiple erosions or ulcerations (more than $10 \mathrm{~cm}$ of bowel length) with hyperaemic, adhesive, or haemorrhagic lesions in the serosa. ${ }^{26}$

\section{STATISTICS}

Data were analysed using analysis of variance with the Scheffe (post hoc) test. All values are expressed as mean (SEM). Statistical significance was set at $\mathrm{p}<0.05$. Regression analysis was performed according to the method of least squares. The confidence interval was set at $95 \%$.

Table 2 Effect of the various diets and combinations on faecal $p H$ and on parameters of microcirculation

\begin{tabular}{|c|c|c|c|c|c|c|}
\hline Diet & Faecal pH & $\begin{array}{l}\text { Adherence (per } \\
100 \text { um venule) }\end{array}$ & $\begin{array}{l}\text { Emigration (per } \\
\text { microscopic field) }\end{array}$ & $\begin{array}{l}\text { Leucocyte rolling } \\
\text { velocity }(\mu \mathrm{m} / \mathrm{s})\end{array}$ & Shear rate $\left(s^{-1}\right)$ & $\begin{array}{l}\text { Macroscopic score } \\
\text { (arbitrary units) }\end{array}$ \\
\hline $\mathrm{FP} / \mathrm{FR}$ & $7.76(0.14)$ & $5.95(0.53)^{\star}$ & $4.15(0.53)$ & $61.2(3.3)$ & 415 (19) & $3.9(0.6)$ \\
\hline US/FR & $7.85(0.09)$ & $4.48(0.44)$ & $1.13(0.19)^{\star}$ & $75.8(3.2)$ & $420(18)$ & $2.5(0.7)$ \\
\hline ST/CR & $7.98(0.24)$ & $3.59(0.42)^{\star}$ & $1.49(0.19)^{\star}$ & 70.7 (3.7) & $409(18)$ & $3.8(0.3)$ \\
\hline ST/ST & $7.99(0.05)$ & $4.71(0.36)$ & $4.57(0.43)$ & $69.8(2.4)$ & 429 (11) & $3.5(0.4)$ \\
\hline US/US & $8.00(0.17)$ & $4.40(0.44)$ & $2.19(0.28)^{\star}$ & $69.4(3.4)$ & $391(17)$ & $2.8(0.8)$ \\
\hline $\mathrm{CP} / \mathrm{FR}$ & $8.01(0.19)$ & $3.48(0.31)^{\star}$ & $3.36(0.33)^{\star}$ & $73.8(4.0)$ & $400(13)$ & $3.7(0.9)$ \\
\hline $\mathrm{FP} / \mathrm{FP}$ & $8.11(0.09)$ & $4.29(0.38)$ & $2.93(0.47)^{\star}$ & $59.1(3.4)$ & $403(17)$ & $2.3(0.2)^{\star}$ \\
\hline $\mathrm{FP} / \mathrm{ST}$ & $8.14(0.25)$ & $3.92(0.38)$ & $4.97(0.81)$ & $68.5(5.3)$ & $440(21)$ & $2.9(0.5)$ \\
\hline $\mathrm{CR} / \mathrm{ST}$ & $8.16(0.16)$ & $3.67(0.48)^{\star}$ & $1.55(0.32)^{\star}$ & $59.3(3.5)$ & $434(25)$ & $2.0(1.0)^{\star}$ \\
\hline US/ST & $8.24(0.35)$ & $3.15(0.32)^{\star}$ & $1.65(0.28)^{\star}$ & $73.3(3.5)$ & $452(19)$ & $3.0(0.3)$ \\
\hline ST/US & $8.25(0.9)^{\star}$ & $3.54(0.44)^{\star}$ & $3.51(0.45)^{\star}$ & $68.1(3.0)$ & $470(19)$ & $2.3(0.7)$ \\
\hline SA/SA & $8.33(0.03)^{\star}$ & $2.29(0.23)^{\star}$ & $1.56(0.22)^{\star}$ & $81.5(2.8)$ & $500(19)^{\star}$ & $1.1(0.5)^{\star}$ \\
\hline $\mathrm{ST} / \mathrm{SA}$ & $8.34(0.02)^{\star}$ & $3.56(0.40)^{\star}$ & $3.32(0.47)^{\star}$ & $69.1(2.8)$ & $411(14)$ & $2.4(0.7)$ \\
\hline $\mathrm{C} 1$ & $8.34(0.12)^{\star}$ & $2.33(0.27)^{\star}$ & $2.00(0.23)^{\star}$ & $70.6(2.7)$ & $493(24)^{\star}$ & $0.8(0.1)^{\star}$ \\
\hline C2 & $8.39(0.03)^{\star}$ & $3.37(0.54)^{\star}$ & $0.68(0.20)^{\star}$ & $72.8(4.5)$ & $487(26)^{\star}$ & $2.3(0.5)^{\star}$ \\
\hline $\mathrm{SA} / \mathrm{FR}$ & $8.42(0.21)^{\star}$ & $2.52(0.22)^{\star}$ & $1.86(0.27)^{\star}$ & $53.6(2.8)$ & $564(17)^{\star}$ & $0.3(0.2)^{\star}$ \\
\hline $\mathrm{CP} / \mathrm{ST}$ & $8.43(0.19)^{\star}$ & $3.53(0.46)^{\star}$ & $2.12(0.34)^{\star}$ & $71.7(3.3)$ & $445(23)$ & $1.8(0.6)^{\star}$ \\
\hline $\mathrm{ST} / \mathrm{CH}$ & $8.46(0.16)^{\star}$ & $3.56(0.26)^{\star}$ & $3.03(0.24)^{\star}$ & $75.6(2.5)$ & $429(11)$ & $0.7(0.2)^{\star}$ \\
\hline $\mathrm{ST} / \mathrm{FR}$ & $8.50(0.07)^{\star}$ & $3.48(0.27)^{\star}$ & $3.95(0.40)$ & $82.2(2.3)$ & 439 (11) & $1.5(0.5)^{\star}$ \\
\hline CR/CR & $8.52(0.14)^{\star}$ & $1.80(0.25)^{\star}$ & $1.06(0.32)^{\star}$ & $65.9(2.8)$ & $475(15)$ & $0.6(0.1)^{\star}$ \\
\hline Control & $8.54(0.06)^{\star}$ & $2.07(0.23)^{\star}$ & $1.43(0.19)^{\star}$ & $77.0(2.5)$ & $526(17)^{\star}$ & $0.6(0.2)^{\star}$ \\
\hline PS1 & $8.56(0.05)^{\star}$ & $2.13(0.21)^{\star}$ & $0.54(0.10)^{\star}$ & $64.6(3.3)$ & $495(24)^{\star}$ & $0.3(0.2)^{\star}$ \\
\hline $\mathrm{HC} 2$ & $8.61(0.18)^{\star}$ & $3.10(0.41)^{\star}$ & $1.62(0.27)^{\star}$ & $61.9(3.2)$ & $485(20)^{\star}$ & $1.1(0.3)^{\star}$ \\
\hline PS2 & $8.64(0.03)^{\star}$ & $1.60(0.20)^{\star}$ & $1.60(0.17)^{\star}$ & $65.4(3.0)$ & $440(19)$ & $1.3(0.8)^{\star}$ \\
\hline $\mathrm{CP} / \mathrm{CP}$ & $8.83(0.14)^{\star}$ & $2.12(0.21)^{\star}$ & $1.89(0.37)^{\star}$ & $62.5(3.0)$ & $435(17)$ & $0.8(0.3)^{\star}$ \\
\hline $\mathrm{HC} 1$ & $8.83(0.15)^{\star}$ & $1.82(0.22)^{\star}$ & $0.92(0.18)^{\star}$ & $72.8(2.7)$ & $537(27)^{\star}$ & $0.3(0.1)^{\star}$ \\
\hline
\end{tabular}

Data are expressed as mean (SEM)

${ }^{\star} \mathrm{p}<0.05 v \mathrm{ST} / \mathrm{ST}$.

ST, standard diet; $\mathrm{CH}$, diet rich in carbohydrates; FR, diet rich in fatty acids; FP, diet poor in fatty acids; CR, diet rich in cholesterol; $\mathrm{CP}$, diet poor in cholesterol; SA, diet poor in saturated fatty acids; US, diet poor in unsaturated fatty acids. All diet combinations (except the control) contain indomethacin. HC, potassium hydrogen citrate; PS, polysulphonic acid; C, cholestyramine; 1, without indomethacin; 2, with indomethacin (all alkalising drugs combined with standard diet). 


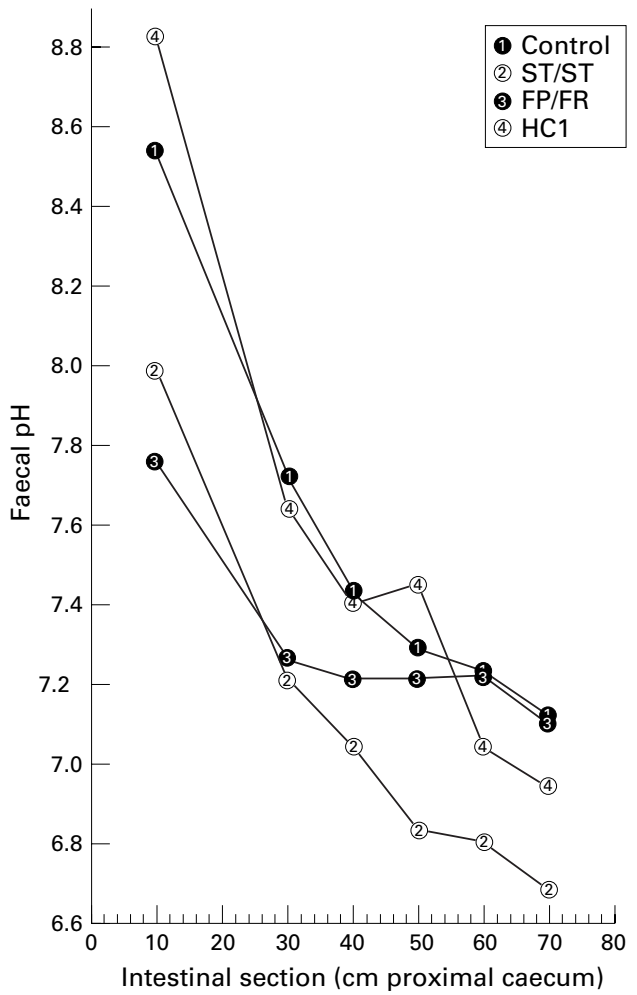

Figure 1 Faecal pH in different sections of small intestine in untreated rats (control), indomethacin treated rats fed with standard diet (ST/ST), indomethacin treated rats fed with a diet poor of fat, later rich in fat (FP/FR), and rats treated with potassium hydrogen citrate without indomethacin $(\mathrm{HCl})$. Mean values are shown.

\section{Results}

Faecal pH of small intestinal contents decreased approaching the ligament of Treitz by approximately $1 \mathrm{pH}$ unit per $70 \mathrm{~cm}$ of bowel. Faecal $\mathrm{pH}$ was also affected by the different diet combinations. Figure 1 shows the $\mathrm{pH}$ shift in the small bowel from the caecum to the ligament of Treitz for four groups of differently treated rats: control (negative control without indomethacin), ST/ST (positive control with indomethacin), FP/FR (treatment inducing the lowest $\mathrm{pH}$ in the bowel section proximal to the caecum), and $\mathrm{HCl}$ (potassium hydrogen citrate treatment without indomethacin inducing the highest $\mathrm{pH}$ in the section proximal to the caecum). For further comparisons the $\mathrm{pH}$ of the lowest section of small bowel was used as intravital microscopy was performed in the mesentery of the last $20 \mathrm{~cm}$ of the ileum.

Table 2 summarises the effects of various diet combinations and of treatment with the various alkalising drugs (sodium hydrogen citrate, polysulphonic acid, cholestyramine) on faecal $\mathrm{pH}$ and microcirculatory parameters. Ten days after induction of indomethacin induced inflammation there was a decrease in faecal $\mathrm{pH}$ compared with the identical fed control group without indomethacin (ST/ST versus control); at the same time leucocyte adherence and emigration were increased significantly, venular wall shear rate was decreased, and leucocyte rolling velocity was not affected. Faecal pH was mainly increased by the different diet combinations compared with the positive control (ST/ST); only the use

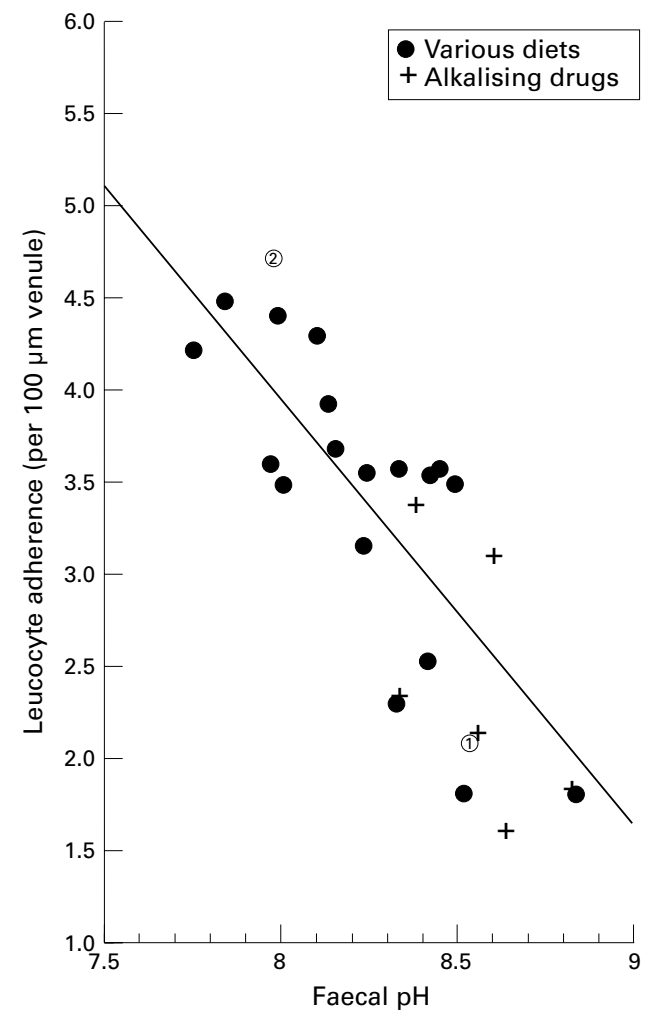

Figure 2 Correlation between faecal $\mathrm{pH}$ and indomethacin induced leucocyte adherence in rats fed with standard diet without (control) or with indomethacin (ST/ST) and treated with various diet combinations or alkalising drugs 10 days after indomethacin administration. Mean values are shown. $y=-2.5 x+24.1$ for the regression line, $r=-0.55, p<0.05$.

of the combinations poor in fat/rich in fat, poor in unsaturated acids/rich in fat, and standard/ rich in cholesterol resulted in lowering of faecal $\mathrm{pH}$ versus the positive control. The reduction or increase in $\mathrm{pH}$ was accompanied by a proportional increase or decrease (correlation coefficient $r=-0.55$ ) in leucocyte adherence (fig 2). Faecal $\mathrm{pH}$ and shear rate were positively correlated $(r=0.48)$ (fig 3), although venular diameter and erythrocyte velocity - from which the shear rate is calculated-were not significantly correlated with faecal $\mathrm{pH}$. There was no correlation between $\mathrm{pH}$, leucocyte emigration $(r=0.13)$ and leucocyte rolling velocity $(r=0.05)$.

Alkalising substances kept faecal $\mathrm{pH}$ in the range of the negative control group (without indomethacin). There was no significant difference in $\mathrm{pH}$ between indomethacin and vehicle treated animals (potassium hydrogen citrate with indomethacin $8.61(0.18)$, without indomethacin, 8.83 (0.15); polysulphonic acid with indomethacin 8.64 (0.03), without indomethacin 8.56 (0.05); cholestyramine with indomethacin 8.39 (0.03), without indomethacin $8.34(0.12))$. Blood $\mathrm{pH}$ was not affected by this treatment (data not shown). Leucocyte adherence was significantly reduced in animals treated with cholestyramine or potassium hydrogen citrate plus indomethacin, and it was normalised to control levels in animals treated with polysulphonic acid plus indomethacin. Administration of alkalising drugs without 


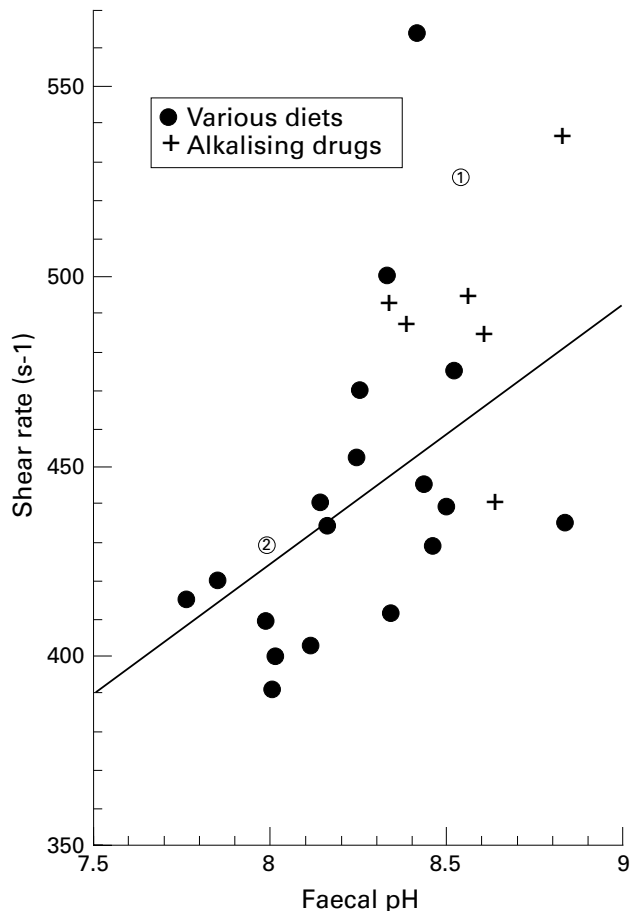

Figure 3 Correlation between faecal $p H$ on venular wall shear rate in rats fed with standard diet without (control) or with indomethacin $(S T / S T)$ and treated with various diet combinations or alkalising drugs 10 days after indomethacin administration. Mean values are shown. $y=$ $87.8 x-278$ for the regression line, $r=0.48, p<0.05$.

indomethacin had no effect on leucocyte adherence.

Macroscopic visible intestinal damage, scored $0-5$ according to the degree of inflammation, was also influenced by the various diet combinations. There was a significant inverse correlation between the degree of macroscopic ulceration and faecal $\mathrm{pH}(r=-0.67)$ (fig 4).

\section{Discussion}

Variations in faecal $\mathrm{pH}$ are caused by differences in nutrition, intestinal bacterial colonisation, and faecal bile acid pattern. ${ }^{10}{ }^{15}$ Previous experiments have shown that artificial variations in diet, alterations in bacterial colonisation by antimicrobial agents, and changes in faecal bile acid pattern may reduce inflammatory activity in the indomethacin model of a long lasting experimental ileitis. ${ }^{3}$ 26-29

The aim of this study was to assess whether there is a comparable decrease in faecal $\mathrm{pH}$ in this model of IBD according to the findings in Crohn's disease, whether the $\mathrm{pH}$ shift is proportional to the intestinal inflammatory activity, and whether the artificial variation in faecal $\mathrm{pH}$ may affect the inflammatory response. Experiments were done in the chronic phase of indomethacin induced ileitis 10 days after application. As the maximum inflammation in the indomethacin model is usually 10 to $20 \mathrm{~cm}$ proximal to the caecum we measured the $\mathrm{pH}$ of the small intestinal contents of this section, which is approximately one $\mathrm{pH}$ unit higher than in the duodenum and intracolonically near the anus. ${ }^{30}$ Inflammatory activity was determined microscopically by measuring the leucocyte endothelial cell interaction in post-

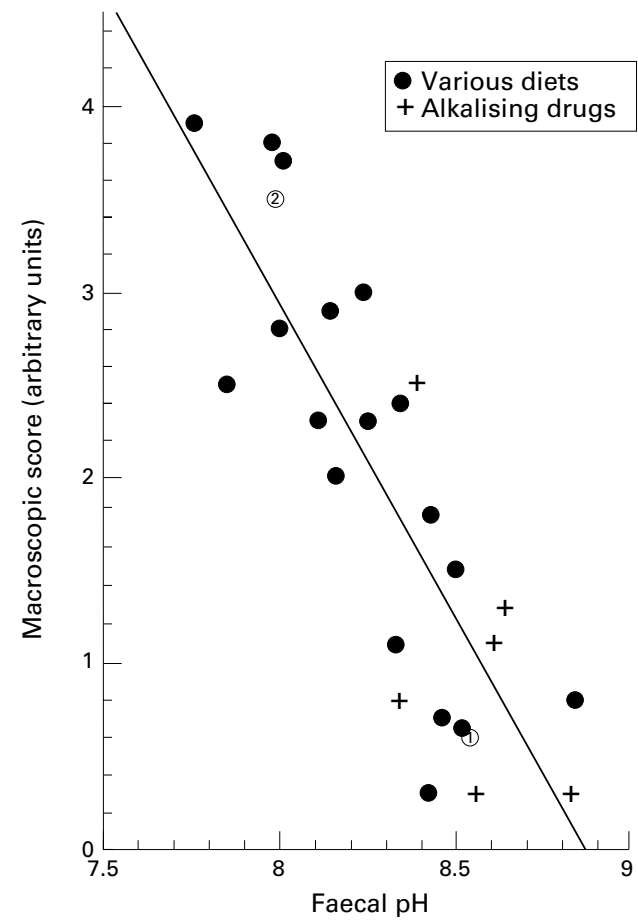

Figure 4 Correlation between faecal pH and macroscopic ulcer score in rats fed with standard diet without (control) or with indomethacin $(S T / S T)$ and treated with various diet combinations or alkalising drugs 10 days after indomethacin administration. Mean values are shown. $y=$ $-0.3 x+29.4$ for the regression line, $r=-0.67, p<0.05$.

capillary mesenteric venules of the same region and macroscopically by scoring intestinal epithelial lesions of the whole small bowel.

As in patients with IBD, indomethacin treated rats fed with a standard diet had a lower $\mathrm{pH}$ and a higher inflammatory activity, shown by an increase in leucocyte adherence and emigration compared with control rats without indomethacin. The $\mathrm{pH}$ shift in the indomethacin model might be due to inhibition of the duodenal bicarbonate response to luminal acidification. ${ }^{31}$ The use of various diet combinations in indomethacin treated rats resulted in an increase or even a further decrease in faecal $\mathrm{pH}$. With some diets $\mathrm{pH}$ was nearly normalised to the level of untreated controls. The fact that $\mathrm{pH}$ variations were not determined by the second diet alone (fed from the onset of inflammation for 10 days until the experiment), but also by the first diet, suggests that very early inflammatory processes which are affected by luminal metabolites before indomethacin administration or long lasting effects of the diets on the bacterial contents are at least partly responsible for the faecal $\mathrm{pH}$ measured.

The $\mathrm{pH}$ variations were accompanied by an inverse proportional effect on leucocyte adherence. Although there was also a direct proportional increase or decrease in shear rate, correlations between $\mathrm{pH}$ and venular diameter or erythrocyte velocity, respectively, from which shear rate is calculated, were not significant due to inconstant changes of both parameters due to $\mathrm{pH}$ shifts. As already shown, ${ }^{32}$ leucocyte rolling velocity in the chronic phase (more than seven days after indomethacin administration) 
of inflammation is not significantly affected by indomethacin treatment.

In order to elucidate the question of whether variations in faecal $\mathrm{pH}$ are a consequence or the cause of alterations in leucocyte endothelial cell adhesion we administered different alkalising substances to standard fed rats with or without indomethacin treatment. While the $\mathrm{pH}$ increasing effect of the anion exchange polymer cholestyramine might be partially due to its additional binding capacity for bile acids and fatty acids, ${ }^{33}$ the observed increases in faecal $\mathrm{pH}$ by potassium hydrogen citrate and polysulphonic acid are probably exclusively due to their alkalising properties. Application to animals not treated with indomethacin induced no further increase in faecal $\mathrm{pH}$ compared with control, untreated rats. In indomethacin treated animals all three substances induced alkalisation of faecal $\mathrm{pH}$ to the same level as in the rats with the same alkaliser but without indomethacin, respectively. At the same time, leucocyte adherence was significantly attenuated or even normalised to the level of untreated control rats. This fact favours the idea that faecal $\mathrm{pH}$ may influence the degree of leucocyte endothelial cell interaction. The lack of correlation of faecal $\mathrm{pH}$ with leucocyte emigration could be due to differences in activation of the various adhesion molecules responsible for leucocyte adherence to and transmigration through the microvascular endothelium, respectively. This has been already described for the differential effect of $P$ selectin on leucocyte adherence and emigration in chronic indomethacin induced inflammation. ${ }^{34}$

Although the reduced mucosal accumulation of granulocytes was not accompanied by protection against indomethacin induced intestinal mucosal ulcerations (there was no correlation between macroscopic ulceration score and leucocyte emigration), there was an inverse correlation between the extent of mucosal ulcerations and faecal $\mathrm{pH}$. It has been shown previously that in the chronic phase of indomethacin induced inflammation granulocyte infiltration into the mucosa is a consequence of intestinal lesions. ${ }^{26}{ }^{35}$ Loss of the normal mucosal barrier to the uptake of macromolecules, bacteria, and bacterial antigens is thought to be an important aspect of Crohn's disease. ${ }^{36}$ An increase in mucosal permeability has also been shown for indomethacin induced ileitis. ${ }^{26}$

A direct effect of low $\mathrm{pH}$ on the mucosal barrier, thereby increasing or reducing the extent of inflammation, seems unlikely. Intrarectal administration of $\mathrm{HCl}$ did not produce colonic inflammation ${ }^{37}$ and variations in $\mathrm{pH}$ per se did not induce intestinal inflammation. ${ }^{10}$ A role of colonic $\mathrm{pH}$ in the production of hydrogen from carbohydrates by colonic bacterial flora was described by Perman et al. $.^{38} \mathrm{Glu}-$ cose metabolism and hydrogen production was $\mathrm{pH}$ dependent and inhibited at acidic $\mathrm{pH}$. Another possibility is an effect of faecal $\mathrm{pH}$ on bacterial colonisation ${ }^{10}$ which might in turn affect mucosal permeability. ${ }^{15}$ We did not detect pathogens on microbiological examin- ation of small intestinal contents of differently fed rats in our experiments, but the intestinal flora present was not further differentiated.

The most important effects of variations in $\mathrm{pH}$ on inflammatory activity could include alterations in the faecal bile acid pattern and direct or, due to alterations in bile composition, indirect changes in enterohepatic circulation of indomethacin. $^{20}$ Approximately $50 \%$ of parenterally given indomethacin undergoes biliary recycling. ${ }^{39}$ In vitro experiments showed that bile of indomethacin treated rats has a concentration dependent higher cytotoxicity in rat epithelial cells than bile of vehicle treated rats or those treated with indomethacin alone. ${ }^{26}$ The increasing hydrophilicity of indomethacin with increasing $\mathrm{pH}^{29}$ would suggest that alkalisation of faeces would reduce the solubility of indomethacin in the bile, resulting in a lower uptake through the lipophilic membranes of the epithelial cells. Furthermore, a shift in faecal pH might change the composition of bile by altering the state of ionisation of the various bile acids and bacterial conversion of primary to secondary bile acids. ${ }^{9} 40$

Other ways in which enteric $\mathrm{pH}$ influences the adhesion of white blood cells in mesenteric venules distant from the circulation of the intestinal mucosa remain speculative. A direct $\mathrm{pH}$ effect could be excluded by normal blood $\mathrm{pH}$ and by the lack of effect of $\mathrm{pH}$ modulation of superfusion buffer directly applied to the mesenteric preparations (unpublished results). Further experimentation is needed to elucidate whether systemic effects of proinflammatory mediators such as leukotriene $\mathrm{B}_{4}$ or tumour necrosis factor $\alpha$-both raised in peripheral blood of patients with IBD - are responsible for the observed effects of faecal $\mathrm{pH}$ on mesenteric leucocyte endothelial cell adhesion, or whether there are local nervous reflex controls for proinflammatory or antiinflammatory mediators similar to those described for postprandial vasodilatation. ${ }^{41}$

The authors thank Jutta Michel and Angelika Lingauer for their excellent technical assistance. This work was supported by the Else-Kroner-Fresenius Foundation.

1 Robert A, Asano T. Resistance of germfree rats to ndomethacin-induced intestinal lesions. Prostaglandins 1977;14:333-41.

2 Sutherland L, Singleton J, Sessions J, et al. Double blind, placebo controlled trial of metronidazole in Crohn's disease. Gut 1991;32:1071-5.

3 Arndt H, Palitzsch K-D, Grisham MB, et al. Metronidazole inhibits leucocyte-endothelial cell adhesion in rat mesenteric venules. Gastroenterology 1994;106:1271-6.

4 Videla S, Vilaseca J, Guarner F, et al. Role of intestinal microflora in chronic inflammation and ulceration of the microflora in chronic inflammatio

5 Vogel CM, Corwin TR, Baue AK. Intravenous hyperalimentation in the treatment of inflammatory bowel disease. Arch

Surg 1974;108:460-7.

6 O'Morain C, Segal AW, Levi AJ. Elemental diets as primary treatment of acute Crohn's disease: a controlled trial. BMF 1984;288:1859-62.

7 Gorard DA, Hunt JB, Payne-James JJ, et al. Initial response and subsequent course of Crohn's disease treated with elemental diet or prednisolone. Gut 1993;34:1198-202.

8 Tragnone A, Valpiani D, Miglio F, et al. Dietary habits as risk factors for inflammatory bowel disease. Eur f Gastroenterol Hepatol 1995;7:47-51.

9 Kruis W, Kalek H-D, Stellaard F, et al. Altered faecal bile acid pattern in patients with inflammatory bowel disease. Digestion 1986;35:189-98.

10 Attebery HR, Sutter VL, Finegold SM. Effect of a partially chemically defined diet on normal human faecal flora. $A m$ $\mathcal{f}$ Clin Nutr 1972;25:1391-8. 
11 Crowther JS, Drasar BS, Goddard P, et al. The effect of a chemically defined diet on the faecal flora and faecal chemically defined diet on the faecal
steroid concentration. Gut 1973;14:790-3.

12 Hayakawa S. Microbial transformation of bile acids. A unified scheme for bile acid degradation and hydroxylation of bile acids. $Z$ Allgem Mikrobiol 1981;22:309-26.

13 Kalambaheti T, Cooper GN, Jackson GDF. Role of bile in non-specific defence mechanisms of the gut. Gut 1994;35: 1047-52.

14 Zhang J-X, Lundin E, Reutering C-O, et al. Effects of rye bran, oat bran and soya-bean fibre on bile composition, gallstone formation, gall bladder morphology and serum cholesterol in Syrian golden hamsters (Mesocricetus auratus). Br f Nutr 1994;71:861-70.

15 Enss ML, Grosse-Siestrup H, Riedesel H. Acidification of the colonic mucins following polyvalent colonization of the germ-free rat. $\mathcal{F}$ Vet Med 1992;39:503-12.

16 Bounous G, Devroede GJ. Effects of an elemental diet on human faecal flora. Gastroenterology 1974;66:210-4.

17 Knutson TW, Koss MA, Hogan DL, et al. Acetazolamide inhibits basal and stimulated $\mathrm{HCO}_{3}$ secretion in the human proximal duodenum. Gastroenterology 1995;108:102-7.

18 Banarjee AK, Peters TJ. Experimental non-steroidal antiinflammatory drug-induced enteropathy in the rat: similarities to inflammatory bowel disease and effect of thromboxane synthetase inhibitor. Gut 1990;31:1358-64.

19 Sartor RB, Bender DE, Holt L. Susceptibility of inbred rat strains to intestinal inflammation induced by indomethacin [abstract]. Gastroenterology 1992;102:A690.

20 Brodie DA, Cook PG, Bauer BJ, et al. Indomethacininduced intestinal lesions in the rat. Tox Appl Pharmaco 1970;17:615-24.

21 Sartor RB. Animal models of intestinal inflammation: relevance to inflammatory bowel disease. In: MacDermott $\mathrm{RP}$, Stenson WF, eds. Inflammatory bowel disease. New York: Elsevier, 1991:337-53.

22 Granger DN, Benoit JN, Suzuki M, et al. Leucocyte adherence to venular endothelium during ischemia/reperfusion. ence to venular endothelium d

23 Arndt H, Smith CW, Granger DN. Leucocyte-endothelial cell adhesion in spontaneously hypertensive and normotencell adhesion in spontaneously hyperten
sive rats. Hypertension 1993;21:667-73.

24 Davis MJ. Determination of volumetric flow in capillary tubes using an optical Doppler velocimeter. Microvasc Re 1987;34:223-30.

25 House SD, Lipowsky H. Leucocyte-endothelium adhesion microhemodynamics in mesentery of the cat. Microvasc Res 1987;34:363-79.

26 Yamada T, Deitch E, Specian RD, et al. Mechanisms of acute and chronic intestinal inflammation induced by indomethacin. Inflammation 1993;17:641-62.

27 Satoh H, Guth PH, Grossman MI. Role of bacteria in gastric ulceration produced by indomethacin in the rat: cytoprotective action of antibiotics. Gastroenterology 1983; 84:483-9.

28 Arndt H, Palitzsch K-D, Schölmerich J. Ursodeoxycholic acid attenuates leucocyte-endothelial cell adhesion in indomethacin-induced intestinal inflammation in the rat [abstract]. Gut 1995;37(suppl 2):A105.

29 Matsumoto T, Iida M, Kuroki F, et al. Effects of diet on experimentally induced intestinal ulcers in rats: morphology and tissue leukotrienes. Gut 1994;35:1058-63.

30 Lin HC, Visek WJ. Large intestinal $\mathrm{pH}$ and ammonia in rats: dietary fat and protein interactions. F Nutr 1991;121:832-43.

31 Takeuchi K, Furukawa O, Tanaka H, et al. Determination of acid-neutralizing capacity in the rat duodenum: influences of 16,16-dimethyl prostaglandin E2 and nonsteroidal antiinflammatory drugs. Dig Dis Sci 1986;31:631-7.

32 Arndt H, Yamada T, Grisham MB, et al. Systemic microcirculatory disturbances induced by indomethacin [abstract]. Gastroenterology 1992;102:A34

33 Vahouny GV, Tombes R, Cassidy MM, et al. Dietary fibers: $\mathrm{V}$. Binding of bile salts, phospholipids and cholesterol from mixed micelles by bile acid sequestrants and dietary fibres. Lipids 1980;15:1018-21.

34 Arndt H, Palitzsch K-D, Anderson DC, et al. Leucocyteendothelial cell adhesion in a model of intestinal inflammation. Gut 1995;37:374-9.

35 Arndt H, Bolanowski MA, Granger DN. Role of interleukin-8 on leucocyte-endothelial cell adhesion in intestinal inflammation. Gut 1996;38:911-5.

36 Shorter RG, Huizenga KA, Spencer RJ. A working hypothesis for the etiology and pathogenesis of nonspecific inflammatory bowel disease. Am F Dig Dis 1972;17:102432.

37 Zeitlin IJ, Noris AA. Animal models of colitis. In: BSG/SK\&F International Workshop, Mechanisms of $\mathrm{BSG} / \mathrm{SK} \& \mathrm{~F}$ International Workshop, Mechanisms of
gastrointestinal inflammation. Stanstead Abbotts, 1983: gastrointest

38 Perman JA, Modler S, Olson AC. Role of $\mathrm{pH}$ in production of hydrogen from carbohydrates by colonic bacterial flora. f Clin Invest 1981;67:643-50.

39 Yesair DW, Callahan M, Remington L, et al. Role of the entero-hepatic cycle of indomethacin on its metabolism, distribution in tissues and its excretion by rats, dogs and monkeys. Biochem Pharmacol 1970;19:1579-90.

40 Meier PJ. Biliary excretion of endogenous and exogenous compounds. In: Siegers C-P, Watkins III JB, eds. Biliary excretion of drugs and other chemicals. Stuttgart, New York: Gustav Fischer, 1991:157-82.

41 Biber B, Lundgren O, Svanvik J. Studies on the intestinal vasodilatation observed after mechanical stimulation of the mucosa of the gut. Acta Physiol Scand 1971;82:177-90. 